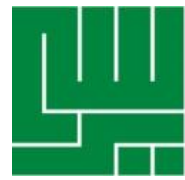

KATA KUNCI

KEYWORDS

ABSTRAK

\section{Hubungan Strategi Coping Orang Tua Terhadap Keberfungsian Keluarga di Kelurahan Cipinang Melayu}

\section{The Relationship Of Parental Coping Strategies To Family Functioning In The Cipinang Melayu Village}

\author{
Evi Syafrida Nasution, Ika Wahyu Pratiwi \\ Fakultas Psikologi, Universitas Borobudur \\ Email: evisyafridanasution@borobudur.ac.id; ikawahyupratiwi@borobudur.ac.id
}

banjir, keberfungsian keluarga, orang tua, strategi coping

floods, family functioning, parents, coping strategies

Keberfungsian keluarga adalah berfungsinya keluarga sebagai wahana untuk mendidik, mengasuh, sosialisasi dan mengembangkan kemampuan seluruh anggotanya agar dapat menjalankan perannya dalam keluarga serta memberikan kepuasan dan lingkungan sosial yang sehat guna tercapainya keluarga sejahtera; namun setiap keluarga tidak terlepas dari suatu masalah (vertical stressor dan horizontal stressor) sehingga diharapkan para orang tua dapat mengambil coping yang tepat dalam menghadapi masalahnya, dalam hal ini menghadapi banjir. Penelitian ini bertujuan untuk mengetahui apakah ada hubungan positif antara strategi coping orang tua terhadap keberfungsian keluarga. Manfaat penelitian ini, diharapkan nantinya dapat menambah pengetahuan orang tua ketika menghadapi permasalahan dalam keluarga, dimana focused problem coping merupakan cara yang tepat untuk digunakan sehingga fungsi keluarga dapat berjalan dengan normal. Jenis penelitian yang digunakan adalah penelitian kuantitatif yang bersifat expost facto. Populasi dalam penelitian ini adalah warga (orang tua) yang bertempat tinggal di Kelurahan Cipinang Melayu yang terkena dampak banjir. Teknik pengambilan sampel yaitu menggunakan simple random sampling, dengan jumlah responden sebanyak 90 orang. Instrumen yang digunakan untuk pengambilan data adalah skala coping stres dan keberfungsian keluarga. Hasil penelitian menunjukkan bahwa nilai korelasi Pearson antara variabel strategi coping dengan keberfungsian keluarga sebesar 0,072. Hal ini menunjukkan bahwa hubungan antara strategi coping dan keberfungsian keluarga sangat lemah. Nilai korelasi positif artinya ada hubungan positif yaitu jika strategi coping stres orang tua meningkat maka keberfungsian keluarga akan meningkat.

ABSTRACT Family functioning is the functioning of the family as a vehicle to educate, nurture, socialize and develop the ability of all its members to be able to carry out their role in the family and provide satisfaction and a healthy social environment to achieve a prosperous family; but every family is inseparable from a problem (vertical stressor and horizontal stressor) so that parents are expected to be able to take appropriate 
coping in dealing with the problem, in this case facing flooding. This study aims to determine whether there is a positive relationship between parental coping strategies on family functioning. The benefits of this research are expected to be able to increase the knowledge of parents when facing family problems, where focused coping is the right way to use so that family functions can run normally. The type of research used is ex post facto quantitative research. The population in this study were residents (parents) who lived in Cipinang Melayu Village affected by the flood. The sampling technique is using simple random sampling, with a number of respondents as many as 90 people. The instrument used for data collection is the stres coping scale and family functioning. The results showed that the value of the Pearson correlation between the coping strategy variables with family functioning was 0.072. This shows that the relationship between coping strategies and family functioning is very weak. Positive correlation value means that there is a positive relationship that is if the stres coping strategies of parents increase, family functioning will increase.

\section{PENDAHULUAN}

Menurut UU Nomor 24 Tahun 2007, bencana adalah peristiwa atau rangkaian peristiwa yang mengancam dan menganggu kehidupan dan penghidupan masyarakat yang disebabkan oleh faktor alam dan/atau faktor non alam maupun faktor manusia sehingga mengakibatkan timbulnya korban jiwa manusia, kerusakan lingkungan, kerugian harta benda, dan dampak psikologis. Berlokasi di Cincin Api Pasifik (wilayah dengan banyak aktivitas tektonik), Indonesia harus terus menghadapi risiko letusan gunung berapi, gempa bumi, banjir dan tsunami. Pada beberapa peristiwa selama 20 tahun terakhir, Indonesia menjadi headline di media dunia karena bencana-bencana alam yang mengerikan dan menyebabkan kematian ratusan ribu manusia dan hewan, serta menghancurkan wilayah daratannya (termasuk banyak infrastruktur sehingga mengakibatkan kerugian ekonomi). Dari uraian tersebut, perlu adanya pelatihan khusus untuk menghadapi terjadinya bencana alam sehingga masyarakat Indonesia mampu mempersiapkan diri dan menghadapi ancaman dari bencana alam (Hilmi dkk, 2012).

Bencana alam dapat memberikan kerugian ekonomi pada masyarakat terdampak. Adanya perubahan cuaca, misalnya musim hujan atau kemarau yang ekstrim (fenomena El Nino dan La Nina) dapat menghancurkan panen bahan makanan, memicu terjadinya inflasi dan menyebabkan tekanan finansial yang berat bagi kalangan kurang mampu di masyarakat Indonesia. Bencana alam dapat terjadi karena akibat ulah manusia (seperti kebakaran hutan yang disebabkan karena budaya pembakaran ladang, biasanya di pulau Sumatera dan Kalimantan) memicu dan menyebabkan dampak-dampak yang sangat besar bagi lingkungan hidup (Wijayanti, 2013).

Sementara itu, menurut WHO (dalam Suharsono dkk, 2016), bencana alam yaitu peristiwa atau kejadian yang mengancam dan mengganggu keberlangsungan kehidupan makhluk hidup. Apapun bentuknya bencana alam tersebut, baik yang diakibatkan oleh faktor alam dan/faktor manusia dapat menyebabkan munculnya korban jiwa, rusaknya lingkungan, kerugian harta benda, dan efek psikologis manusia (dalam Suharsono dkk, 2016).

Bencana banjir merupakan salah satu bencana alam yang selalu terjadi di berbagai Wilayah Negara Kesatuan Republik Indonesia. Terjadinya banjir dapat disebabkan oleh kondisi alam yang statis 
seperti geografis, topografis, dan geometri alur sungai (pola pengaliran sungai/irigasi dan bentuk tanah dari aliran sungai tersebut (Sastrodiharjo, dalam Amri, dkk, 2016). Banjir Jakarta merupakan bencana yang hampir setiap tahun terjadi di ibukota, namun yang membedakan adalah luas wilayah terdampaknya. Berdasarkan data BPBD DKI Jakarta menunjukkan bahwa Provinsi DKI Jakarta dilewati 13 sungai dan 70 kawasan rawan banjir, meliputi 37 kecamatan, 125 Kelurahan, dan 634 RW. Banjir pada tahun 2013 adalah banjir besar yang terjadi menggenangi $508 \mathrm{RW}$ di 124 kelurahan di DKI Jakarta. Banjir ini menjadikan 83.930 orang mengungsi selama beberapa hari dan 38 orang meninggal dunia (Nugroho, Suprapto, \& Pandanwangi, 2016).

Meningkatkan pengetahuan akan risiko bencana dapat mengurangi dari jumlah dari masyarakat yang terdampak. Dengan pengetahuan yang lebih baik/pelatihan khusus, dihimbau masyarakat dapat mempersiapkan diri dan tanggap terhadap situasi yang darurat sehingga dapat mengurangi dampak kerusakan, kerugian serta lingkungan yang mungkin terjadi sebagai akibat dari terjadinya bencana alam tersebut (http://www.berkasedukasi.com).

Walsh (dalam Juliyanti dkk, 2014) memberikan model penilaian komprehensif proses keluarga yang normal. Menurutnya, normalitas keluarga bisa dilihat dalam empat kriteria yaitu kesehatan atau ketiadaan penyakit (health or the absence of patology), visi ideal atau optimal keberfungsian keluarga, statistik rata-rata, proses normal termasuk siklus kehidupan keluarga. Keluarga yang fungsional adalah keluarga yang dapat menjalankan fungsifungsinya. Maksudnya keberfungsian keluarga yang optimal yang terlihat dari bagaimana tindakan yang diperlihatkan oleh masing-masing anggota keluarga (Yusuf, dalam Juliyanti dkk, 2014). Shek (dalam Juliyanti dkk, 2014) menyatakan bahwa peran keluarga mengacu pada mutu dari kesejahteraan dan kemampuan yang dimiliki masing-masing anggota keluarga, serta kelebihan dan kekurangan keluarga. Ketika keluarga menghadapi masalah dapat mencari solusi dari masalah yang dihadapi. Masalah yang timbul biasanya terjadi karena komunikasi yang kurang baik. Setiap individu memiliki dan melaksanakan perannya masing-masing, peduli dengan anggota keluarga yang lain maka keluarga tersebut telah melaksanakan kebefungsian keluarga yang optimal (Ryan, Epstein, Keitner, Miller \& Bishop, dalam Juliyanti dkk, 2014). Menurut Berns (dalam Lestari, 2016) keluarga memiliki lima fungsi dasar yaitu reproduksi, sosialisasi/edukasi, penugasan peran sosial, dukungan ekonomi, dukungan emosi/pemeliharaan. Dari sudut pandang ilmu perkembangan, peran yang paling penting untuk mengasuh anak yang baik dan dapat berkembang serta berinteraksi dengan baik pula, memerlukan pengasuhan dan lingkungan yang baik. Di sisi lain, pola asuh orang tua sangat dibutuhkan untuk perkembangan anak, sehingga terjalin komunikasi atau interaksi yang baik antara orang tua dan anak. Terjalinnya komunikasi atau interaksi antara orang tua dan anak banyak yang dapat dipelajari oleh anak, misalnya kepercayaan terhadap agama yang diyakini, aturan-aturan yang berlaku di dalam keluarga maupun di masyarakat sehingga anak dapat menunjukkan tingkah laku yang sesuai dengan norma yang ada.

Bagaimana keberfungsian keluarga perlu kiranya dikaji lebih mendalam, agar mendapatkan gambaran bagaimana keluarga terutama orang tua menjalankan fungsi dasar tersebut karena hal ini akan berpengaruh terhadap pengasuhan yang diberikan kepada anak-anak. Meskipun demikian, tidak semua keluarga dapat menjalankan fungsi-fungsi dasar tersebut karena adanya masalah yang dihadapi. Untuk memastikan keluarga tetap menjalankan fungsinya saat situasi bencana, maka perlu diketahui faktor-faktor apa saja yang berhubungan dengan keberfungsian keluarga. dengan mengetahui faktor tersebut, maka dapat diupayakan tindakan 
yang dapat memaksimalkan keberfungsian keluarga.

Salah satu faktor yang peneliti duga berkorelasi dengan keberfungsian keluarga adalah strategi coping yang dilakukan orang tua. Adapun alasan peneliti menduga demikian dikarenakan setiap orang tua memiliki caranya sendiri-sendiri dalam mengatasi permasalahan yang dihadapi keluarganya dengan baik dan tepat. Upaya yang dapat dilakukan orang tua untuk dapat beradaptasi terhadap stressor tergantung bagaimana coping yang dimiliki oleh orang tua tersebut.

Strategi coping dipengaruhi oleh penilaian kognitif pada setiap individu. Strategi coping diperlukan untuk mengatasi stres dari eksternal maupun dari internal. Antonovsky (dalam Puspitacandri, 2014) menggunakan metode generalisasi untuk menggambarkan sumber karakteristik resisten pada individu dalam mengelola stres. Karakteristiknya yaitu fisik, biokimia, kognitif, emosional, sikap, interpersonal, makro sosial budaya. Strategi untuk menghadapi stres dapat dibedakan menjadi dua, yaitu strategi coping yang memfokuskan pada problem atau emosi (problem-and emotion-focuse coping) dan strategi coping dengan cara mendekati atau menghindari stres (approach vs. avoidant coping) (Lestari, 2016). Coping adalah proses dinamis yang merespon kepada perubahan dalam kondisi penuh stres.

Di dalam keluarga, orang tua tentunya yang lebih bertanggung jawab dalam menyelesaikan masalah yang dihadapi keluarga dibandingkan dengan anak-anak. Berbagai strategi coping bisa saja dilakukan dan orang tua secara berkelanjutan dapat mengevaluasi kembali situasi untuk menentukan apakah usaha coping mereka berhasil atau tidak dalam menghadapi masalah. Strategi coping orang tua bertujuan untuk mengatasi situasi dan tuntutan yang dirasakan menekan, menantang, membebani dan melebihi sumber daya yang dimiliki keluarga, atau mempertahankan berbagai tujuan rumah tangga, misalnya pemenuhan konsumsi pangan, kesehatan, dan status sosial ekonomi. Coping merupakan cara yang dilakukan oleh seseorang dalam menyelesaikan permasalahan yang dihadapinya baik itu masalah yang muncul dalam kehidupan sehari-hari atau keadaan tertentu. Cara yang dilakukan oleh orang tua dalam mengatasi permasalahan di dalam keluarga merupakan hal yang paling penting karena akan berkaitan dengan peran yang dilakukan orang tua di dalam keluarga (Stuart, 2009). Seperti halnya yang dikemukakan oleh Hsiao (dalam Gour \& Pandey, 2016) bahwa hubungan antara orang tua memainkan peran besar dalam menentukan mekanisme coping yang diadopsi keluarga dan tingkat stres yang terkait dengan mereka

Berfungsi atau tidaknya sistem keluarga sebagai akibat dari perubahan dunia luar, akan mempengaruhi bagaimana keluarga tersebut menghadapi berbagai permasalahan yang ada. Seiring perjalanan hidupnya yang diwarnai tantangan faktor internal dan faktor eksternal, setiap keluarga mengalami perubahan yang beragam. Pada proses pertumbuhan dan perkembangan keluarga, ada yang berhasil dengan memuaskan, ada yang memiliki kekurangan (deficit) atau bahkan ada yang gagal (failed). Ada keluarga yang kokoh dalam menerapkan fungsinya tetapi ada juga keluarga yang mengalami keretakan dan ketidakharmonisan sehingga menjadi tidak berfungsi secara optimal (Astuti, dalam Lestari, 2016).

Kemampuan-kemampuan keluarga dan anggota untuk bertahan dalam menghadapi tantangan dapat diwujudkan apabila anggota keluarga: (a) mempunyai strategi penyelesaian (coping strategy) untuk menangani peristiwa kehidupan yang normal dan bukan normal; (b) mengamalkan ciri fleksibel dan adaptif dalam mengidentifikasi dan mendapatkan sumber bagi memenuhi kebutuhan; (c) Ilmu dan keterampilan yang digunakan untuk mengidentifikasi kebutuhan dan menetapkan hasil; (d) kemampuan untuk memelihara ciri positif dalam semua aspek 
kehidupan termasuk melihat krisis dan tantangan sebagai peluang untuk berkembang; (e) kemampuan untuk menggerakkan anggota keluarga untuk memperoleh sumber-sumber yang diperlukan; (f) kemampuan mewujudkan dan melanggengkan hubungan harmonis di dalam dan di luar sistem keluarga; (g) kemampuan merencanakan menyusun tujuan keluarga.

Merujuk pada berbagai pemaparan di atas, maka peneliti berasumsi bahwa perlu dilakukan penelitian lebih lanjut mengenai keberfungsian keluarga, dengan mengkaitkan variabel yang lebih spesifik yakni strategi coping orang tua. Adapun permasalahan penelitian yang akan dijawab dalam penelitian ini adalah "apakah terdapat hubungan antara strategi coping orang tua dengan keberfungsian keluarga"?

\section{METODE PENELITIAN Pendekatan Penelitian}

Penelitian ini menggunakan metode kuantitatif. Penelitian kuantitatif merupakan metode untuk menguji teori-teori tertentu dengan cara meneliti hubungan antar variabel. Variabel-variabel ini diukur (biasanya dengan instrumen penelitian) sehingga data yang terdiri dari angka-angka dapat dianalisis berdasarkan prosedur statistik. Penelitian ini bersifat kuantitatif dengan desain penelitian ini yaitu crosssectional design, dimana data penelitian tersebut didapat sekaligus. Peneliti mengambil data dari berbagai variabel penelitian dalam satu kurun waktu tertentu (Periantalo, 2016).

\section{Partisipan Penelitian}

Teknik pengambilan sampel yaitu menggunakan simple random sampling, dengan jumlah responden sebanyak 90 orang. Penelitian ini dilakukan terhadap orang tua yang bertempat tinggal di Kelurahan Cipinang Melayu, Kecamatan Makasar, Jakarta Timur. Jumlah yang telah ditetapkan untuk dijadikan sampel penelitian sebagai 90 orang. Partisipan dalam penelitian ini mayoritas berada di antara 30-44 tahun sebanyak 33,3\%, berjenis kelamin perempuan sebanyak 49,5\% dan tamatan SLTA sebanyak 37,8\%.

\section{Hipotesis Penelitian}

$\mathrm{H}_{\mathrm{o}}$ : Tidak ada hubungan yang positif antara strategi coping orang tua terhadap keberfungsian keluarga.

$\mathrm{H}_{\mathrm{a}}$ : Ada hubungan yang positif antara strategi coping orang tua terhadap keberfungsian keluarga.

\section{Instrumen Penelitian}

Skala Keberfungsian Keluarga

Skala keberfungsian keluarga yang digunakan disusun berdasarkan pada dimensi-dimensi yang dikemukakan oleh Moos dan Moos (2002), yaitu: (1) dimensi relationship, aspek-aspeknya adalah cohesion, expressiveness, conflict; (2) dimensi personal growth, aspek-aspeknya adalah independence, achievement orientation, intellectual-cultural orientation, active-recreational orientation, moral-religious emphasis; (3) dimensi system maintenance, aspek-aspeknya adalah: organization dan control. Skala ini terdiri dari 60 aitem, aitem yang gugur sebanyak 28 aitem dan aitem yang valid sebanyak 33 aitem. Kriteria pemilihan aitem, berdasarkan pada koefisien korelasi aitem total minimal 0,20. Sementara itu, skor reliabilitas alat ukur skala keberfungsian keluarga ialah sebesar 0,729 sehingga skala penelitian ini dinilai reliabel.

\section{Skala Strategi Coping}

Skala strategi coping disusun berdasarkan pada dimensi-dimensi yang dikemukakan oleh Lazarus dan Folkman (1984), aspek-aspek kemampuan coping diambil dari dua bagian strategi coping, yaitu (1) problem focused coping, aspekaspeknya yaitu plantul problem solving, coping confrontatif, coping seeking social support; (2) emotional focused problem, aspek-aspeknya yaitu coping positive reappraisal, coping accepting 
responsibility, coping self controlling, coping distancing, coping escape avoidance. Skala ini terdiri dari 40 aitem, aitem yang gugur sebanyak 8 aitem dan aitem yang valid sebanyak 32 aitem. Kriteria pemilihan aitem, berdasarkan pada koefisien korelasi aitem total minimal 0,20. Sementara itu, skor reliabilitas alat ukur skala strategi coping ialah sebesar 0,738 sehingga skala penelitian ini dinilai reliabel.

\section{Teknik Analisa Statistik}

Data penelitian dianalisis secara statistik dengan menggunakan analisis korelasi Product Moment dari Pearson dengan menggunakan bantuan perangkat lunak SPSS versi 22.

\section{HASIL}

\section{Deskripsi Hasil Penelitian}

Deskripsi hasil penelitian diperoleh dari hasil perhitungan statistik skor strategi coping dan keberfungsian keluarga yang dibagikan kepada partisipan penelitian. Hasil perhitungan tersebut kemudian dikategorisasikan ke dalam dua kategori, yaitu kategori tinggi dan rendah.

\section{Kategorisasi Skor}

Peneliti menentukan kategorisasi strategi coping, untuk memudahkan menghitung nilai maksimum, minimum, rata-rata, standar deviasi, dan jumlah total (sum). Mean yang didapat adalah sebesar 47,03 dan standar deviasi sebesar 11,958. Nilai minimum yang didapatkan adalah 19 dan nilai maksimum adalah 86, sehingga luas jarak sebenarnya adalah $86-19=67$. Jarak tersebut kemudian dibagi dua untuk dilihat nilai tengahnya yaitu $67 / 2=33,5$. Kemudian hasil tersebut ditambah dengan nilai minimum yaitu $33,5+19=52,5$. Sehingga nilai tengah yang didapatkan antara 19 dan 86 adalah 52,5. Dengan demikian, diperoleh kategorisasi sebagaimana tergambar pada Tabel 1 .

\section{Tabel 1}

\section{Kategorisasi Skor Strategi Coping}

\begin{tabular}{llll}
\hline $\begin{array}{l}\text { Kategor } \\
\text { isasi }\end{array}$ & $\begin{array}{l}\text { Interval } \\
\text { Skor }\end{array}$ & $\begin{array}{l}\text { Freku } \\
\text { ensi }\end{array}$ & $\begin{array}{l}\text { Persenta } \\
\text { se }\end{array}$ \\
\hline $\begin{array}{l}\text { Strategi } \\
\text { coping } \\
\text { tinggi }\end{array}$ & $52,5-86$ & 30 & $27 \%$ \\
$\begin{array}{l}\text { Strategi } \\
\text { coping } \\
\text { rendah }\end{array}$ & $19-52,5$ & 60 & $54 \%$ \\
\hline
\end{tabular}

Berdasarkan tabel 1, terlihat bahwa sebanyak 30 responden $(27 \%)$ memiliki strategi coping tinggi dan sebanyak 60 responden $(54 \%)$ memiliki strategi coping rendah. Dengan demikian dapat dikatakan bahwa responden dalam penelitian ini mayoritas memiliki strategi coping yang rendah yaitu sebanyak 54 responden (54\%).

Sementara untuk data skor keberfungsian keluarga, mean yang didapat adalah sebesar 121,62 dan standar deviasi sebesar 14,106. Nilai minimum yang didapatkan adalah 77 dan nilai maksimum adalah 164, sehingga luas jarak sebenarnya adalah $164-77=87$. Jarak tersebut kemudian dibagi dua untuk dilihat nilai tengahnya yaitu $87 / 2=43,5$. Kemudian hasil tersebut ditambah dengan nilai minimum yaitu $43,5+77=120,5$. Sehingga nilai tengah yang didapatkan antara 77 dan 164 adalah 120,5. Dengan demikian, diperoleh kategorisasi sebagaimana tergambar pada Tabel 2.

Tabel 2

Kategorisasi Skor Keberfungsian Keluarga

\begin{tabular}{llll}
\hline Kategorisasi & $\begin{array}{l}\text { Interval } \\
\text { Skor }\end{array}$ & $\begin{array}{l}\text { Freku } \\
\text { ensi }\end{array}$ & $\begin{array}{l}\text { Perse } \\
\text { ntase }\end{array}$ \\
\hline $\begin{array}{l}\text { Keberfungsi } \\
\text { an keluarga } \\
\text { tinggi }\end{array}$ & $120,5-$ & 44 & $39,6 \%$ \\
$\begin{array}{l}\text { Keberfungsi } \\
\text { an keluarga } \\
\text { rendah }\end{array}$ & $77-$ & 46 & $41,4 \%$ \\
& 120,5 & & \\
\end{tabular}

Berdasarkan tabel 2, terlihat bahwa sebanyak 44 responden (39\%) memiliki keberfungsian keluarga tinggi dan sebanyak 46 responden $(41,4 \%)$ memiliki 
keberfungsian keluarga rendah. Dengan demikian dapat dikatakan bahwa responden dalam penelitian ini mayoritas memiliki keberfungsian keluarga yang rendah yaitu sebanyak 46 responden $(41,4 \%)$.

\section{Uji Normalitas}

Berdasarkan uji normalitas strategi coping dengan Kolmogorov-Smirnov. Didapat nilai 0,112 yang lebih besar dari $\alpha$ $=0,05$, jadi berdasarkan nilai yang didapat maka Ho diterima. Sehingga dapat disimpulkan bahwa data strategi coping berdistribusi normal. Uji normalitas skala keberfungsian keluarga dengan Kolmogorov-mirnov dengan nilai 0,200 yang lebih besar dari $\alpha=0,05$, jadi berdasarkan nilai yang didapat maka Ho diterima. Dengan demikian, dapat disimpulkan bahwa data keberfungsian keluarga berdistribusi normal.

\section{Uji Hipotesis}

Dalam rangka menguji apakah terdapat hubungan yang signifikan antara strategi coping dengan keberfungsian keluarga, peneliti menggunakan rumus correlate bivariate dengan jenis korelasi Pearson Product Moment.

Pengujian hipotesis perlu dilakukan untuk mengetahui apakah koefisien korelasi yang didapatkan signifikan pada taraf signifikan yang ditentukan atau tidak. Ho diterima jika rhitung $<1$ os 0,05 .

\section{Tabel 3}

\section{Hasil Uji Hipotesis}

Korelasi antara Strategi Coping dan Keberfungsian keluarga

\begin{tabular}{ll}
\hline $\mathbf{r}$ & .072 \\
Sig. & .500 \\
$\mathbf{N}$ & 90
\end{tabular}

Berdasarkan hasil uji hipotesis sebagaimana tergambar pada Tabel 3, diketahui bahwa taraf signifikansi yang didapatkan adalah sebesar 0,500, dimana $0,500>1$ os 0,05. Dengan demikian, Ha (hipotesis alternatif) yang menyatakan ada hubungan yang signifikan antara strategi coping orang tua dengan keberfungsian keluarga ditolak, dan Ho (hipotesis nol) yang menyatakan tidak ada hubungan yang signifikan antara strategi coping orang tua dengan keberfungsian keluarga diterima. Dengan diterimanya Ho, berarti dapat disimpulkan bahwa tidak ada hubungan yang signifikan antara strategi coping orang tua dengan keberfungsian keluarga.

Selain itu, penelitian ini mendapatkan koefisien korelasi (r) hitung sebesar 0,072. Besaran korelasi antara strategi coping orang tua dan keberfungsian keluarga yang diperoleh yaitu sebesar 0,072 yang bermakna bahwa keeratan hubungannya rendah; sedangkan $r$ yang bernilai positif, menunjukkan bahwa arah variabel-variabel berkorelasi positif, yaitu jika variabel yang satu meningkat, maka variabel lainnya cenderung meningkat. Hal ini berarti bahwa semakin tinggi strategi coping orang tua maka semakin tinggi keberfungsian keluarga. Sebaliknya, semakin rendah strategi coping orang tua maka semakin rendah keberfungsian keluarga.

\section{DISKUSI}

Melalui hasil pengolahan data, dapat disimpulkan bahwa tidak terdapat hubungan antara strategi coping orang tua dengan keberfungsian keluarga. Hasil ini tidak sesuai dengan teori dan penelitian sebelumnya. Dari hasil uji hipotesis didapatkan pula nilai koefisien korelasi (r) hitung sebesar 0,072 yang bermakna bahwa keeratan hubungannya rendah. sedangkan $r$ yang bernilai positif, menunjukkan bahwa arah variabel-variabel berkorelasi positif, yaitu jika variabel yang satu meningkat, maka variabel lainnya cenderung meningkat.

Hasan (2002) mengungkapkan bahwa koefisien korelasi menunjukkan jenis/arah korelasi dan kuat atau tidaknya hubungan dari dua variabel atau lebih kuat 
atau tidaknya hubungan variabel dapat dilihat dari nilai atau besaran koefisien korelasi yang didapatkan. Menurut Sugiyono (dalam Priyatno, 2016), koefisien korelasi antara 0,00-0,199 diinterpretasikan bahwa hubungan antara dua variabel sangat rendah.

Hasil penelitian ini menunjukkan bahwa tidak ada hubungan antara strategi coping dengan keberfungsian keluarga. Hal ini mungkin dikarenakan bahwa keberfungsian keluarga banyak dipengaruhi oleh faktor-faktor lainnya yang mungkin lebih memiliki hubungan yang kuat, dimana dalam penelitian ini tidak diukur hubungannya. Tinjauan literatur menunjukkan bahwa prediktor yang diketahui untuk fungsi keluarga termasuk karakteristik demografi, seperti jenis kelamin, usia, status perkawinan, tingkat pendidikan, pekerjaan, dan status ekonomi (Bello'n dkk, 1996; Chung, dalam Cao dkk, 2013). Sementara itu, variabel keluarga seperti struktur keluarga, dukungan keluarga dan gaya coping juga diidentifikasi sebagai prediktor signifikan untuk fungsi keluarga (Nojima dkk, 1994; Youngblut \& Brooten, dalam Cao dkk, 2013).

Peneliti merasa masih terdapat banyak kekurangan dalam penelitian ini sehingga memperbesar kemungkinan timbulnya error yang dapat mempengaruhi hasil penelitian. Adapun keterbatasan penelitian ini mungkin dikarenakan oleh terbatasnya jumlah sampel penelitian sehingga kurang mewakili populasi. Gravetter dan Wallnau (2009) memberikan penjelasan mengenai hal ini melalui the law of large numbers, yakni semakin besar ukuran sampel, hal atau nilai yang ingin diukur semakin mempresentasikan nilai yang sebenarnya pada populasi. Selain itu, dalam penelitian ini peneliti tidak mengukur faktor lain yang lebih berpengaruh terhadap keberfungsian keluarga seperti karakteristik demografi, struktur keluarga dan dukungan keluarga.

\section{SIMPULAN}

Berdasarkan analisis data yang telah dilakukan sebelumnya, dapat ditarik kesimpulan bahwa tidak terdapat hubungan yang signifikan antara strategi coping orang tua dengan keberfungsian keluarga.

\section{SARAN}

Berikut ini beberapa saran teoritis dan praktis yang diajukan oleh peneliti yang dapat dijadikan pertimbangan untuk penelitian selanjutnya, yaitu:

\section{Saran Teoritis}

Untuk penelitian selanjutnya diharapkan dapat memperbanyak jumlah sampel. Hal ini dijadikan pertimbangan mengingat jumlah kepala keluarga (KK) yang banyak di Kelurahan Cipinang Melayu. Selain itu diharapkan dapat melakukan penelitian terhadap faktor atau aspek psikologis lainnya yang lebih berpengaruh terhadap keberfungsian keluarga seperti karakteristik demografi, struktur keluarga dan dukungan keluarga.

\section{Saran Praktis}

Dalam upaya meningkatkan keberfungsian keluarga diharapkan orang tua dapat meningkatkan pendapatan keluarga agar terpenuhinya salah satu keberfungsian keluarga yaitu memastikan stabilitas ekonomi dan meningkatkan status sosial.

\section{Ucapan Terima Kasih}

Penelitian yang dilakukan oleh penulis pertama (Evi Syafrida Nasution) dan penulis kedua (Ika Wahyu Pratiwi) merupakan penelitian yang dilakukan oleh kedua penulis melaalui skema Hibah Dosen Pemula. Ucapan terima kasih dan penghargaan setinggi-tingginya diberikan kepada Kementerian Riset, Teknologi, dan Pendidikan Tinggi, Direktorat Jenderal Penguatan Riset dan Pengembangan yang memungkinkan penelitian ini terlaksana. 
Amri, M. R. (2016). Risiko bencana Indonesia. Jakarta: BNPB.

Cao, X., Jiang, X., Li, X., Hui Lo, M. C. J., \& Li, R. (2013). Family functioning and its predictors among disaster bereaved individuals in China: Eighteen months after the Wenchuan earthquake. PLoS ONE,8(4).https://doi.org/10.1371/journ al.pone.0060738.

Gour, S., \& Pandey, N. (2016). Coping mechanisms and parental relationship in the families of a child with autism spectrum disorder. The International Journal of Indian Psychology, 3(3), 8393.

Gravetter, F. J., \& Wallnau, L. B. (2009). Statistics for the behavioral science. Belmont: Thomson Wadsworth.

Hilmi, E., Hendarto, E., Riyanti., \& Sahri, A. (2012). Analisis potensi bencana abrasi dan tsunami di pesisir Cilacap. Jurnal Penanggulangan Bencana, 3(1), 35-42.

Juliyanti, dkk., (2014). Hubungan antara keberfungsian keluarga dengan pengungkapan diri remaja terhadap orang tua pada siswa SMA Krista Mitra Semarang. Empati, 3(4), 422-431.

Lestari, S. (2016). Psikologi keluarga. Jakarta: Prenadamedia Group.

Lazarus, R. S., \& Folkman, S. (1984). Stres, appraisal, and coping. New York: Springer Publisher Company.

Moos, R. H., \& Moos, B. S. (2002). Family environment scale manual. Palo Alto, CA: Consulting Psychologists Press.

Nugroho, S. P., Suprapto, \& Pandanwangi, T. S. (2016). Kerjasama sipil-militer dalam penanggulangan bencana (Studi kasus tanggap darurat banjir Jakarta 203, 2014, 2015). Jurnal Dialog Penanggulangan Bencana, 7(2), 103110.

Periantalo, J. (2016). Penelitian kuantitatif untuk psikologi. Yogyakarta: Pustaka Pelajar.

Priyatno, D. (2016). SPSS handbook. Yogyakarta: MediaKom

Puspitacandri, A. (2014). Strategi coping dalam mengatasi stres - studi pada ibu bekerja dan tidak bekerja. In Taufiqurrahman et.al (Eds.), Ketahanan keluarga sebagai aset bangsa: Family, marriage, parenting. Prosiding Seminar Nasional Universitas Merdeka mmalang. Malang, Indonesia.
Stuart, G. W. (2009). Principles and practice of psychiatric nursing $\left(9^{\text {th }}\right.$ ed. $)$. Mosby Inc.

Suharsono, dkk., (2016). Penerapan hasil penelitian psikoedukasi dalamm penurunan masalah psikososial keluarga pasca bencana di masyarakat sebagai upaya promotip, preventip, kuratip dan rehabilitatif di Dusun Jemblung, Desa Sampang, Kecamatan Karangkobar, Kabupaten Banjarnegara. Jurnal LINK, 12 (1), 12-14.

Wijayanti, A. R. W. (2013). Perubahan pekerjaan masyarakat sebagai akibat dari bencana, studi kasus kawasan wisata Volcano Tour Gunung Merapi, Desa Umbulharjo, Kecamatan Cangkringan, Kabupaten Sleman. Jurnal Perencanaan Wilayah dan Kota, 24(1). 